\title{
Enzymic Synthesis of Mimoside : A Metabolite of Mimosine in Mimosa pudica and Leucaena leucocephala
}

Mimosine (I), which is found in large quantities in the legume species Mimosa pudica and Leucaena leucocephala, is converted rapidly into mimoside (II) in the young seedlings of these species. ${ }^{1)}$ Mimoside forms a very minor component of seeds and mature plants of M. pudica and L. leucocephala. However, its concentration increased rapidly in Leucaena seedlings grown in the dark for $3-5$ days at $30^{\circ}$; during further growth of the plants, the concentration of mimoside fell gradually to a very low level.

We now wish to report the enzymic synthesis of mimoside from mimosine and uridine diphosphate-glucose (UDP-glucose) catalyzed by extracts from Leucaena seedlings (Fig. 1).

Leucaena seedlings were grown in moistened vermiculite in the dark at $30^{\circ}$. After harvest, the testas were removed and the seedlings were cooled at $0^{\circ}$ for $30 \mathrm{~min}$ before extraction. All subsequent operations were carried out at about $0^{\circ}$. Seedlings were macerated normally in $0.1 \mathrm{~m}$ potassium phosphate buffer containing $0.5 \%$ 2-mercaptoethanol, $\mathrm{pH} 8.3, \quad(0.5 \mathrm{ml} / \mathrm{g}$ seedlings $)$. After expressing through fine nylon,

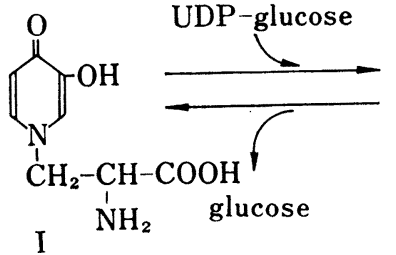<smiles></smiles>

Fig. 1. Scheme for the Biosynthesis of Mimoside and its Hydrolysis by Enzymes in Leucaena Seedlings the extract was centrifuged at $25000 \mathrm{~g}$ for $20 \mathrm{~min}$ to obtain a clear supernatant. The supernatant was applied to a column of Sephadex G-25 (fine) equilibrated with $0.1 \mathrm{~m}$ potassium phosphate buffer, $\mathrm{pH} 8.3$, which was eluted with $0.1 \mathrm{~m}$ potassium phosphate buffer, $\mathrm{pH} 8.3$, to obtain a protein-containing solution free from low mol. wt. substances. The protein eluate was directly used as the crude enzyme preparation.

The normal reaction mixture used to demonstrate mimoside biosynthesis contained UDP-glucose or UDP-(U-14 C)-glucose $(5 \mu$ mole., $0.5 \mu \mathrm{Ci})$, mimosine $(2 \mu \mathrm{mole})$ and $0.2 \mathrm{ml}$ enzyme preparation (equivalent to $0.4 \mathrm{~g}$ seedling fresh weight) in a final volume of $0.5 \mathrm{ml}$ (normally maintained at $\mathrm{pH} 8.3$ by $0.1 \mathrm{~m}$ potassium phosphate buffer). Mixtures were incubated at $30^{\circ}$ and reaction was stopped by addition of ethanol (3 vol.). Precipitated protein was. removed by centrifuging, and the residual supernatant was examined chromatographically for the presence of mimoside. Control mixtures lacking either UDP-glucose or minosine were examined simultaneously: mimoside was not detected after incubation of such mixtures, nor when a boiled enzyme preparation $\left(100^{\circ}\right.$ for $\left.5 \mathrm{~min}\right)$ was used.

The product obtained in these experiments was identified by its chromatographic behaviour in comparison with that of authentic mimoside (mp 178-179,$[\alpha]_{\mathrm{D}}^{28}-60.9^{\circ}(c=0.46$ in water)), obtained from Leucaena seedlings, ${ }^{1)}$ using the following solvent systems: 1 , butan-1-ol-formic acid-water $(4: 1: 1 \mathrm{v} / \mathrm{v}) ; 2$, butan-1-ol-acetic acid-water $(90: 10: 29, \mathrm{v} / \mathrm{v})$; 3 , phenol-ethanol-water $(3: 1: 1, \mathrm{w} / \mathrm{w}) ; 4$, butan-1-ol-pyridine-water $(1: 1: 1, \mathrm{v} / \mathrm{v}) ; 5$, butan-1-ol-acetic acid-water $(4: 1: 1, \mathrm{v} / \mathrm{v})$. The $R f$ values for mimoside obtained in these solvents were $0.11,0.02,0.12,0.40$, and 0.05 , respectively, whilst mimosine had the following $R f$ data; $0.24,0.08,0.20,0.19$, and 0.14 , respectively. Under the same conditions, UDP-

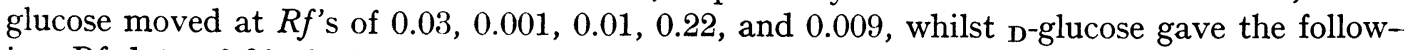
ing $R f$ data; $0.20,0.14,0.19,0.51$, and 0.17 , respectively. Therefore, mimoside was well 
separated from mimosine and UDP-glucose when papers were developed in solvent 1 above. Mimoside could be detected on the chromatograms by using ninhydrin.

Further confirmation of the identity of the reaction product as mimoside was obtained using an automatic amino acid analyzer (Shibata model AA-500, Tokyo). Under standard operating condition $\left(150 \mathrm{~cm}\right.$ column, $50^{\circ}, 0.2 \mathrm{~N}$ sodium citrate buffer, $\mathrm{pH} 3.25$, flow rate $0.5 \mathrm{ml} / \mathrm{min}$ ), mimoside eluted from the column at about $3 \mathrm{hr}$, i.e. at a position between S-methylcysteine sulfoxide and methionine sulfoxide, whilst mimosine appeared at a position closed to an isoleucine reference peak. For routine assay of mimoside formation, the amino acid analyzer was employed with a smaller column $\left(50 \mathrm{~cm}, 50^{\circ}, 0.2 \mathrm{~N}\right.$ sodium citrate buffer, $\mathrm{pH} 4.25$, flow rate $0.5 \mathrm{ml} / \mathrm{min}$ ), which allowed rapid quantitative determinations to be made: the mimoside was now eluted at $62 \mathrm{~min}$, whilst mimosine was eluted at $110 \mathrm{~min}$.

Mimoside formation was determined by measuring ${ }^{14} \mathrm{C}$-incorporation from UDP-(U-14 C)glucose into mimoside. After separation on paper chromatograms, radioactivity associated with ninhydrin-positive substances was measured using a gas-flow $4 \pi$ radiochromatogram scanner (Aloka model PCS-2B, Tokyo). The migration of the major radioactive spot corresponded with authentic mimoside.

The amount of mimoside formed from UDP-glucose and mimosine is proportional to time over a period of at least $45 \mathrm{~min}$ and reached a maximum value (about $96 \%$ yield) at about $60 \mathrm{~min}$.

The addition of 2-mercaptoethanol or dithiothreitol to the buffer solution used in the .extraction procedure increased the yield of enzyme, but sulfhydryl reagents added at a later stage to reaction mixtures had no effect on mimoside formation. This finding is in contrast to that of Kleinhofs, Haskins, and Gorz, ${ }^{2)}$ who reported that the glucosylation of 2-hydroxytrans-cinnamic acid by cell-free extracts of Melilotus alba had an absolute requirement for 2-mercaptoethanol or cysteine. Mimoside formation was not dependent upon added magnesium ions. The enzyme had a $\mathrm{pH}$ optimum of $8.2-8.4$ by using $0.1 \mathrm{~m}$ potassium phosphate buffer and was more active in $0.1 \mathrm{~m}$ potassium phosphate than in $0.1 \mathrm{~m}$ Tris- $\mathrm{HCl}$ buffer.

The glucosyltransferase exhibits a high specificity for UDP-glucose; no detectable mimo-

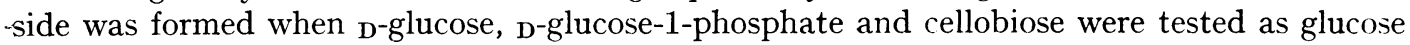
¿donors.

When L-tyrosine and L-3, 4-dihydroxyphenylalanine (L-DOPA) were incubated separately with UDP-glucose and the enzyme system under similar conditions, tyrosine was converted into the corresponding o-glucoside at a very slow rate, i.e. about $0.1 \%$ of that observed with UDP-glucose and mimosine. L-DOPA did not react with UDP-glucose under these conditions. The product's identity as L-tyrosine-O- $\beta$-D-glucoside was confirmed using an automatic amino acid analyzer under standard condition described above: both the prorduct and an authentic sample of L-tyrosine-O- $\beta$-D-glucoside ${ }^{3)}$ were eluted after about $480 \mathrm{~min}$, i.e. at a position before that of glycine $(510 \mathrm{~min})$. A preliminary experiment in which (U${ }^{14} \mathrm{C}$ )-L-tyrosine was supplied to Leucaena seedlings suggested that tyrosine-O-glucoside was formed as a metabolite in very low yield after 3 days: the radioactive L-tyrosine-O-glucoside was identified by co-chromatography with authentic L-tyrosine-O- $\beta$-D-glucoside on amino :acid analyzer coupled at the outlet of the column to a Packard model 3002 flow cell scintililation system.

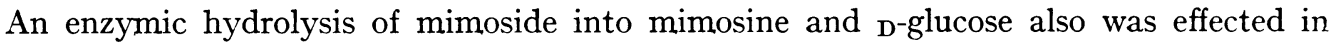
- $0.1 \mathrm{~m}$ acetate buffer, $\mathrm{pH} 5.6$, by similar seedling extracts (Fig. 1); mimosine and D-glucose -were determined by the same method as reported in a previous paper. ${ }^{1)}$ At present, it is not certain whether the formation of mimoside and tyrosine-O-glucoside in vivo is catalyzed

2) A. Kleinhofs, F.A. Haskins, and H.J. Gorz, Phytochem., 6, 1313 (1967).

.3) P.O. Larsen, H. Sorensen, and P. Sorup, Presented at the IV. Intern. Symp. Biochem. and Physiol. of Alkaloids, Halle, 1969: Abh. Dtsch. Akad. Wiss., in press (private communication). 
by the same enzyme and whether O-glucosides are normal metabolites of the corresponding hydroxyamino acids. These questions are being studied further.

Acknowledgement We are grateful to Prof. L. Fowden, Department of Botany and Microbiology, University College London, for his encouragement during the course of this work and for his critical review of the manuscript. We also are indebted to Prof. P.O. Larsen, Department of Organic Chemistry, Royal Veterinary and Agricultural College, Copenhagen, Denmark, for an authentic sample of L-tyrosine-O- $\beta$ D-glucoside.

\author{
Faculty of Pharmaceutical Sciences, \\ University of Chiba \\ 1-33, Yayoi-cho, Chiba
}

Received October 30, 1971

\author{
IsAmu Murakoshi \\ Hiroyuki Kuramoto \\ SHigeru OHMiYa \\ Joju Haginiwa
}

\section{Syntheses of New 6,9,6 Ring System, 5H-Dibenz[b.g]azonine Derivatives}

Most psychotropic drugs have tricyclic dibenzo ring system.

Major parts of them have concerned with 6,6,6 ring system (e.g. phenothiazine or acrydane) or $6,7,6$ ring system (e.g. dibenzocycloheptane or dibenzazepine). Although as a part of $6,8,6$ ring system, many dibenz $[b . f]$ azocines have been synthesized, ${ }^{\mathbf{1})}$ their homologue, $5 \mathrm{H}$-dibenz $[b . g]$ azonines have not yet been reported. We report herein the first syntheses of $6,11,12,13$-tetrahydro-5H-dibenz $[b . g]$ azonines having unknown ring system.

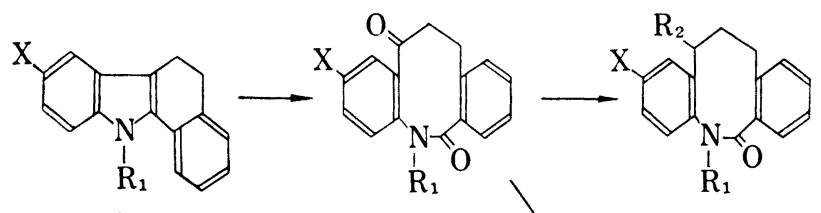

$$
\begin{aligned}
& \text { a : } X=H, R_{1}=H \\
& \text { b :X }=\mathrm{Cl}, \mathrm{R}_{1}=\mathrm{H} \\
& \text { c }: X=\mathrm{H}, \mathrm{R}_{1}=\mathrm{CH}_{2} \mathrm{COOC}_{2} \mathrm{H}_{5}
\end{aligned}
$$

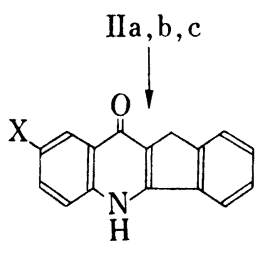

$\mathrm{Va}^{5}, \mathrm{~b}$<smiles>O=C1CCCC(Nc2ccccc2O)N1</smiles>

VI<smiles>CC(C)c1ccccc1CCC(O)c1ccccc1N</smiles>

IV<smiles>Cc1ccc2[nH]c3c(c2c1)CCC3</smiles>

VII

Chart 1

1) e.g. F. Sowinski and H.L. Yale, Arz. Forsch., 14, 117 (1964); O. Schindler, R. Blaser, and F. Hungiker, Helv. Chim. Acta, 49, 985 (1966). 